\title{
Valuing food and ourselves
}

\begin{tabular}{|c|c|}
\hline Sitopia & $\begin{array}{l}\text { Sitopia: How Food Can } \\
\text { Save the World }\end{array}$ \\
\hline sosont & By Carolyn Steel \\
\hline $\begin{array}{l}\text { How Food } \\
\text { Can Save }\end{array}$ & \\
\hline Carolyn Steel & $\begin{array}{l}\text { CHATTO \& WINDUS: } 2020 . \\
\text { 374PP. } € 16.99 .\end{array}$ \\
\hline
\end{tabular}

$\mathrm{t}$ is impossible to read a book completely disassociated from your surroundings;

the time, place and context in which we pick up a new or familiar tome will always influence how we read it, and in turn the emotions, lessons and inspiration we take from it.

In the last week before London went into our now familiar lockdown, I attended the book launch for Carolyn Steel's Sitopia, the follow-up to her 2008 book Hungry City. The impending quarantine was not lost on any of us, but Steel herself was able to pilot us, at least for an evening, through the descending gloom with an infectious wit and optimism that is also infused throughout a sometimes abstract, somewhat meandering but always enjoyable examination of how food is simultaneously the most important thing in our world and the least valued part of our society.

The title, an invented word, comes from the final chapter of Hungry City and is meant to conceptualize how we might achieve our nearest form of utopia by placing food at the centre of our economic, social and even political systems. While Hungry City stepped in levels from the farm to the market to the table and eventually the wastebin to examine how urban spaces 'feed themselves', Sitopia moves within nested layers of space and time, bodies and countries, serving as a book-length rejoinder to the corporate executive who wanted a simple technological solution for our overstretched and inadequate food system and dismissed her answer of asking ourselves what constitutes a good life. As Steel explained both in person and in the book, if something is cheap then we do not value it; the expectation of constantly cheap and ever-present food is not only a function of a system that denigrates plant and animal life and decimates the nutrition that comes from it, but also dehumanizes each of us by separating us from the joy and work of good food.

This is not to say that everybody should or could be like the farmers of Brooklyn Grange, the world's largest rooftop farm in New York City that Steel visits in chapter five, or like the foragers on the coast of Devon in south England who take her in search of wild Alexander (one bite of a seed pod brings "an immediate explosion of flavour, the intense mixture of celery and black pepper") and sea aster (which, she notes, is available at upscale supermarkets for $£ 22$ per kilo). But the question of scale undergirds and occasionally threatens to upend the entire book, as the 'good life' of making, cooking and enjoying your own food is as rare of a commodity for humans as anything that can be foraged from a remote shoreline. Hundreds of millions of people have been forced to leave farms to try their luck in the cities, while in developed countries, entire generations have grown up without producing their own food and are now struggling to even buy flour and yeast to learn how to bake bread during quarantine. The prospect of ten billion mouths by mid-century makes lab-grown beef seem, to tech CEOs anyway, as much of a moral crusade as a new line for revenue. How then can Steel maintain hope for returning to pastoral systems that provide a good life for as many living organisms (from the microorganisms in the soil to the microbiome in our stomachs) as possible?

Because the 'good life' goes beyond what and how much we make to also ask why we do it this way. The middle of the book goes into extended riffs on political philosophy and income inequality, from Thomas Hobbes to Thomas Piketty, as Steel brings the reader to understand that the creation of private property and the division of labour that has turned us into workers and consumers has detached us from the production of valuable work and thus has separated us from ourselves, each other and our surroundings. Her solution, for all intents and purposes, is a healthy dash of anarchism, as the philosophy of Peter Kropotkin's 'self-organizing communities' of Fields, Factories and Workshops is leavened with Henry George's land tax and Elinor Ostrom's common pool resources to form the basis of a new land regime and food paradigm that is as decentralized, organic and localized as possible; the question of scale is thus, potentially, turned upside down.

But it's still a lot of mouths to feed, and more than once while reading Sitopia over these past months I would glance at the time to see if I should go check if the bare shelves in my local shop in central London had been restocked with fresh fruit or bags of rice. Sitting in that bookstore, knowing but still not really knowing what was descending upon the world, I felt bad for Steel that her book should come out on the verge of a global crisis (much as Hungry City came out in the spring of 2008), but as we wrote in our Editorial last month (Nat. Plants 6, 429; 2020), there are hopeful shoots of a 'food sovereignty' movement in which people are realising the limits and drawbacks of industrial agriculture and meat production as well as the connective delight of sourdough, gardens and community. Her book is what we need right now to help us frame the challenges we face towards the solutions we have known all along but resisted because they weren't cheap or easy; if we value ourselves, then we'll restructure our food system in line with natural limits, social stability and personal growth. Utopia, in the words of Eduardo Galeano, may lie at the horizon, but Sitopia may be just the place for us to gather, rest, eat and enjoy the long walk there.

\section{Reviewed by Ryan Scarrow}

Published online: 15 June 2020 https://doi.org/10.1038/s41477-020-0698-z 